\title{
Counterproductive Work Behaviour: The Role of Work Overload and Organizational Justice Dimensions among Employees in Nigeria Private Sector Organizations
}

Nnaebue, Collins I., Etodike, Chukwuemeka E., Nwangwu, Nneka I. \& Ibenyenwa, Mary Chigozie

To Link this Article: http://dx.doi.org/10.6007/IJARBSS/v10-i11/7955

DOI:10.6007/IJARBSS/v10-i11/7955

Received: 18 September 2020, Revised: 12 October 2020, Accepted: 15 November 2020

Published Online: 30 November 2020

In-Text Citation: (Nnaebue, 2020)

To Cite this Article: Nnaebue, C. I. (2020). Counterproductive Work Behaviour: The Role of Work Overload and Organizational Justice Dimensions among Employees in Nigeria Private Sector Organizations. International Journal of Academic Research in Business and Social Sciences, 10(11), 1305-1317.

Copyright: @ 2020 The Author(s)

Published by Human Resource Management Academic Research Society (www.hrmars.com)

This article is published under the Creative Commons Attribution (CC BY 4.0) license. Anyone may reproduce, distribute, translate and create derivative works of this article (for both commercial and non-commercial purposes), subject to full attribution to the original publication and authors. The full terms of this license may be seen at: http://creativecommons.org/licences/by/4.0/legalcode

Vol. 10, No. 11, 2020, Pg. 1305 - 1317

Full Terms \& Conditions of access and use can be found at http://hrmars.com/index.php/pages/detail/publication-ethics 


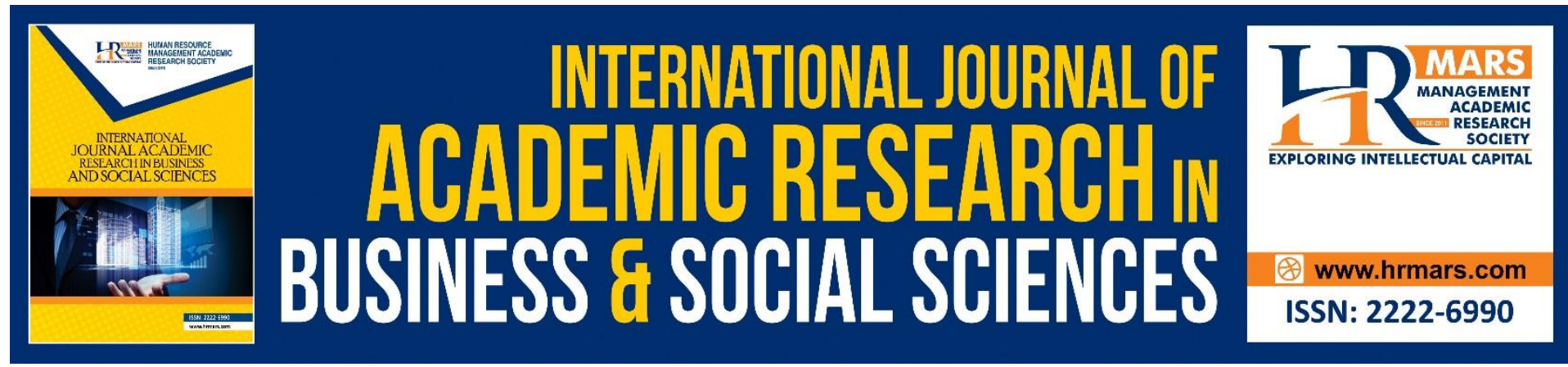

\title{
Counterproductive Work Behaviour: The Role of Work Overload and Organizational Justice Dimensions among Employees in Nigeria Private Sector Organizations
}

\author{
${ }^{1}$ Nnaebue, Collins I., ${ }^{2}$ Etodike, Chukwuemeka E. PhD, \\ ${ }^{3}$ Nwangwu, Nneka I. \& ${ }^{4}$ Ibenyenwa, Mary Chigozie \\ ${ }^{1-3}$ Dept. of Psychology, Nnamdi Azikiwe University Awka, Nigeria, ${ }^{4}$ Dept. of Social Sciences, \\ School of General Studies, Federal Polytechnic Oko \\ Email: ${ }^{1}$ ci.nnaebue@unizik.edu.ng, ${ }^{2}$ nwangwunneka@gmail.com,nelsonetodike@gmail.com \\ \&4imchigozie@gmail.com
}

\begin{abstract}
Due to the growing employment rate, employees' voices may not be heard but they speak in salient ways especially regarding their organizational climate as regards work load and uneven distribution of organizational rewards and punishments. Considering that these circumstances elicit employees' reaction, this study explored the roles of work overload and organizational justice dimensions on counterproductive work behaviour (CWB). The design was correlation design while regression statistics was used to analyze the predictive effects of work overload and organizational justice dimensions on CWB. Sample for the study was 85 employees, 44 males (51.8\%) and 41 females (48.2\%) drawn with the aid of purposive and cluster sampling. Participants' ages range from 20 to 57 at an average age of 34.02 years. CWB scale, Distributive justice index, and Work overload scale were instruments for data collection. The result revealed that employees were high on counterproductive work behaviour and that the predictive effects of work overload on CWB was positive and significant at $\beta(3,385)=.57^{*}, p$ $<.05$ implying that with greater work overload on employees CWB increased proportionally. However, predictive effects of distributive justice (DJ) and procedural justice (PJ) were negative and significant at $\beta(3,385)=.52$ and $.40, p<.05$ respectively implying that as the justice dimensions (distributive and procedural) improved, CWB reduced proportionally. The study recommends that management of organizations should shun exploitation and enthrone fair treatment of employees across board irrespective of ethnic background, age, religion, and gender to reduce CWB and improve organizational efficiency.
\end{abstract}

Keywords: Counterproductive Work Behaviour, Employees, Organizational Justice, Organizational Climate, Retaliatory Work Behaviours, Work Overload.

\section{Introduction}

Organizational climate to a large extent influence most organizational processes and the members of the organization positively or negatively with certain organizational outcomes. 
Naturally, organizational climate influences the nature and extent of employee involvement in their organizations (Joe-Akunne et al., 2018). Depending on organizational exigencies and organizational members' background and dispositions, climatic factors in the organization can become a determining factor for organizational outcomes such that if the climate is supportive and favourable, positive organizational and employee outcomes may follow and if not; negative behaviour such as counterproductive workplace behaviours may ensue. According to Syal (2019), both ethical climate and responsible leadership have implication for employee outcomes; and such outcomes may be helpful or destructive to employees and organizational processes (Etodike et al., 2020; Etodike et al., 2017). In the light of these contentions, the current study evaluated and revalidated the relationship among overload, organizational justice and counterproductive workplace behaviour among private sector employees in the Nigerian private sector organizations.

Counterproductive workplace behavior is behavior that is antithetical to organizational progress and if not controlled may predispose an organization to retrogression or obsolete state (Ansari et al., 2013). According to Sackett et al. (2006), counterproductive work behavior is also employee behavior that goes against the legitimate interests of an organization which can harm organizations or people in organizations including employees and clients, customers, or patients. Ansari et al. (2013) identified two main implications and costs of counterproductive work behaviour viz: financial costs (such as productivity loss, law suits and compensation, reputation) and social costs (such as mental and physical injuries, psychological withdrawal, job dissatisfaction). In Nigeria, despite the costs and prevalence of counterproductive behaviors in organizations; information related to it is limited, obviously because of the problems of unemployment in Nigeria which has seen many employees lose their voice because organizations have become exploitative of their employees knowing that employees do not have alternatives in the face of growing unemployment (Etodike et al., 2018) thus, employees are mute and hapless with CWB being the only option for expressing themselves. Although, many studies attempted to provide the impacts of work overload and organizational justice in the organization however, without linking how it affects employee behaviour for instance Ezeh and Etodike (2017) only established that work overload and organizational justice influenced stress levels of the employee and without determining if whether its effects led to a positive or negative employee outcome in the course of their duties. Thus, in this perspective, the authors hypothesize that organizational factors such as organizational justice and work overload are more likely to predispose employees to counterproductive workplace behavior.

Considering possible negative antecedents of work overload and organizational justice, the following objectives of the study was pursued:

i. To ascertain if participants are high on counterproductive workplace behaviour

ii. To ascertain if work overload predicted counterproductive workplace behaviour among the participants

iii. To ascertain if work organizational justice dimensions (distributive, procedural and interactive) predicted counterproductive workplace behaviour among the participants

iv. To ascertain the relation between work overload and organizational justice. 


\section{Review}

Organizational climates have many outcomes (Syal, 2019). Supportive climates have correlated positive outcomes such as employee participation in decision making (Ike et al., 2017) as well as negative outcomes. These negative outcomes can hurt the organization in many ways ranging from negative employee behaviour e.g. injurious cyber-loafing (Etodike et al., 2020), corruption and office abuse (Ezeh, et al., 2018), abusive supervision and cynicism (Etodike et al., 2017) and even employee turnover (Ezeh et al., 2017). Depending on the nature of organizational climate, employees may be influenced to take actions or inactions considered injurious to organizational wellbeing (Yusof et al., 2019). Also, human conflicts in the organizations which may be caused by workplace incivility may lead to retaliatory behaviours which may be counterproductive to the organization (Etodike \& Ezeh, 2017). Organizational climate may support employees' innovative behaviour as well as create a frustrating atmosphere or even lead to work-to-family conflict (Ezeh et al. 2020). In job outcomes, organizations are often faced with problems of counterproductive behaviours among their employees; however, the threat posed by counterproductive workplace behaviour is very inimical to any organizations' drive towards sustainable growth. This ugly behaviour according to Fagbohungbe et al. (2012) is characterized by employee theft, fraud and sabotage, as well as playing mean pranks, acting rudely, and arguing. They further noted that the impetus for the growing interest in work place counterproductive behaviour is obvious considering the increasing prevalence of this type of behaviour in the workplace and the enormous economic and social costs associated with such behaviours (Fagbohungbe et al, 2012). Studies have shown that both financial impact and socio-psychological consequences of counterproductive work place behaviour on the organization is huge (Ehigie \& Sholola Hameed, 2020; Hassard et al., 2018) and has become a concern for many organizations and stakeholders. Thus, the incidence of workplace counterproductive behaviour and its concomitant cost on the organization calls for an incisive empirical evaluations into its peculiar behavioural tendency among employees with a focus on the organizational factors that are tacit in engendering and perpetuating such behaviour.

Counterproductive work behavior (CWB) also refers to voluntary behavior in that employees either lack motivation to conform to or become motivated to (Ariani, 2013). Counterproductive work behaviors (CWB) are behaviors that are intended to harm the organization and its stakeholders (Spector \& Fox, 2005). The most common CWB typology distinguishes between CWB targeted at the organization and CWB targeted at the individuals (Robinson \& Bennett, 1995). Spector et al. (2006) proposed a more refined taxonomy consisting of five dimensions: abuse, production deviance, sabotage, theft, and withdrawal. There are many reasons why workers may engage in counterproductive work behaviour; for instance, there is corruption (Ezeh \& Etodike, 2017) and exploitation workers which leaves them unsatisfied in life because they do not feel that their rewards are proper and as such may not cater for them in view of the anxiety and stressful conditions associated with retirement in old age except if they were supported (Etodike et al., 2017). This ugly behavior may be triggered by many organizationally related factors including organizational justice and work overload.

Organizational justice refers to an employee's perception of fair treatment on the job (Greenberg, 1987). It is an arbitrary perception of fairness in comparison to employee's knowledge and understanding of counterparts treatments and conditions in similar positions 
(Wu et al., 2016); thus, the importance and function of fairness in the workplace cannot be overemphasized in any organizational setting (Greenberg, 1987). Greenberg (1990) observes that theorists in the field of organizational justice have differentiated between conceptualizations of justice that deal with the content of fairness, or what the decisions are, which is known as distributive justice, and those that centre on the process of fairness, or how decisions are made, referred to procedural justice. In other words, there are three major forms of organizational justice: distributive, procedural, and interactional. Whether employees feel that there is justice or not has an implication and outcome on the job and the organization. For instance, feelings of injustice may lead employees for various forms of sharp practices, corruption and office abuse (Ezeh, 2018) especially if the aspect of the justice has to do with distributive justice or fairness in reward system. Distributive justice refers to the perceived fairness of decision outcomes. It is promoted by following appropriate norms (e.g., equity) for allocating resources such as pay raise (Colquitt \& Greenberg, 2003). Distributive justice outcomes are generally economical (e.g., bonus), but they can also be social for instance promotion (Tritschler \& Steiner, 2005). Distributive justice especially as regards inequity in resource allocation is a known primary motivation for various types of deviant acts (Al-A'wasa, 2018; Wu et al., 2016). For instance, Wu et al. (2016) explored the relationship between perceived organizational justice and the counterproductive work behavior (CWB) of Chinese public servants. In their study the authors assumed that job burnout mediates the relationship between perceived organizational justice and CWB and that moral identity moderates the relationship between job burnout and CWB. The established relationship between organizational justice and CWB is indicative of the effects of the organizational climate in modeling employee behaviours and organizational outcomes.

Distributive justice results from situations where individuals form a judgment of an unfair outcome. It is expected that actions taken as the result of an inequity assessment would be directed toward equity restoration (Adams, 1963). For example, in semi-structured interviews with retired garment workers, Al-A'wasa (2018) found that distributive injustice was an essential cause for workers to commit theft, sabotage, or mutilation, as workers felt that the organization owed them. Tufail (2017) found that perceived inequities result in employee property and production deviance in a variety of industries. Procedural justice refers to the perceived fairness of the procedures used to make decisions. It is maintained by making decisions in a consistent, accurate, and unbiased manner (Colquitt \& Greenberg, 2003). Procedural justice theory suggests that individuals form fairness judgments not only based on the outcomes received, but also based on the procedures used to determine these outcomes. A procedure is judged to be unfair if it indicates a negative relationship with authority or low status group membership (Tyler \& Lind, 1992). Research has shown that procedural justice can have a strong impact, independent of distributive justice, on a variety of attitudinal and behavioral outcomes (Sweeney \& McFarlin, 1993). Evidence shows that unfair decisionmaking processes can lead to various negative consequences (Ike et al., 2017) such as lower performance, higher turnover intentions, theft, and low organizational commitment. Interactional Justice refers to the perceived fairness of how organizational decision-makers enact decisions, and consists of two components (interpersonal and informational). The interpersonal component is promoted with dignified and respectful treatment, whereas the informational one is maintained with adequate and honest explanations (Colquitt \& Greenberg, 2003). This is supported by Tufail (2017) criteria for fair interpersonal treatment; in order to be considered just, there should be respect (courteousness), truthfulness (candid, 
honest communication), justification (explanation of decisions), and propriety (avoidance of improper remarks or statements). When organizations are just in dealing with their employees, they may also exploit their labour leading to work overload.

Work overload in the views of Thiagarajan et al. (2006) is a role stressor perceived by an individual who does not have adequate time or energy to meet incompatible role expectations. Nwankwo, et al. (2013) opined that work overload refers to a situation where multiple work demand exceeds available resource and may either be qualitative or quantitative. For Greenglass et al. (2003) qualitative overload refers to employees' perception that they have too many tasks to perform within a specified time. Inversely, qualitative overload refers to the difficulty in executing a given task (Nwankwo et al, 2013). Such overload, coupled with injustice in the organization may propel the employees to start exhibiting negative compensatory behavior that are counterproductive to organizational aims and objectives. Overload is part of injustice in the organization with stressful outcome (Ezeh, \& Etodike, 2017) with several negative employee consequences including counterproductive.

\section{Framework}

\section{The Stress Facilitation Theory}

The stress facilitation theory was propounded by Jones (1982) as organizational climate theory to explain the relationship between negative (stressful) organization environment and negative employee behaviour (CWB) such as theft, tardiness, cyber-loafing etc. The theory posits that when more dishonest employees experience heightened job stress, their feelings of distress facilitate a multiplicative theft response (Jones, 1982). Researchers have consistently documented that employees who endorse dishonest attitudes toward theft are reliably more likely to steal at work than job candidates and employees who endorse intolerant and punitive attitudes toward theft. Moreover, distressed workers are more likely to engage in on-the-job counter productivity than less stressed employees. Yet based on the Stress Facilitation Theory, employees with favourable attitudes toward theft who are also experiencing debilitating stress will steal significantly more cash, merchandise, and property from their employers than both (a) non-distressed employees with equally favourable attitudes toward theft, and (b) both distressed and non-distressed employees with intolerant and punitive attitudes toward theft. This theory finds support in Nigeria as the nation itself (through corruption) reinforces those that steal from their employers or government who were not caught, mostly the civil or public servants who snatch the nation's income and store them away in foreign banks; they are given national honours by the federal government. It is possible that this antecedent may have equally spread to the private sector organizations.

\section{Method}

Design - The Design for the study was correlation design which intends to explore the relationship between predictor variables and criterion variable; and between the predictor variables. The statistics adopted was regression analysis.

Participants - In this study, 385 participants 199 (51.6\%) of the participants were males while 186 (48.2\%) were females derived from the organized private sector organization in Asaba, Delta State, Nigeria. To select the participants, purposive and cluster sampling technique was adopted. The ages of the participants ranged between 20 and 57 years, with a mean age of 34.02 years and standard deviation of 5.74. 
Instruments - In this study, counterproductive work behavior scale, organizational justice scale, and work overload scale were measures for data collection. Counterproductive work behavior (CWB) is made up of 33 item counterproductive work behaviour by Spector et al. (2006). The Response options range from 1 (never) to 5 (every day), with high scores representing higher incidence of counterproductive work behaviour. Spector et al. (2006) with respect to the reliability of the scale reported that coefficient alpha of .81 was obtained under the counterproductive work behavior scale. For organizational justice, Perceptions of distributive justice developed by Price and Mueller (1986) was used. Items are re-worded to accommodate the use of a 7-point scale ranging from (1) "strongly disagree" to (7) "strongly agree." For example, "How fair has the company been in rewarding you when you consider the responsibilities you have?" was changed to "My supervisor has fairly rewarded me when I consider the responsibilities I have". The original scale was measured on a five-point Likerttype scale from (1) "very unfair" to (5) "very fair." Each item asks for the extent to which the respondent believes that he or she is fairly rewarded on the basis of some comparison with responsibilities, education and training, effort, stresses and strains of job, and performance. All reliabilities reported have been above .90 , and the scale has shown discriminant validity in relation to job satisfaction and organizational commitment (Moorman, 1991). For Procedural justice, Perceptions of procedural justice developed by Niehoff and Moorman (1993) was adopted. It is a 15-item scale which consists of two factors namely: systematic and informational justice, that are consistent with taxonomy of procedural justice. Among the 15 items, six items $(1,2,3,4,5,6)$ measure the degree to which job decisions include mechanisms that ensure the gathering of accurate and unbiased information, employee voice, and an appeals process, while nine items $(7,8,9,10,11,12,13,14,15)$ measure the degree to which employees feel their needs are considered in, and adequate explanations are made for, job decisions. In other words, among the 15 items, six items were designed to measure the fairness of formal procedures (i.e., systematic justice) in the organization as revealed by procedures which promote consistency, bias suppression, accuracy, appropriateness, representativeness, and ethicality. Nine items were designed to measure supervisor consideration of employee rights, treatment of employees with respect and kindness, and provision of explanations and justification for decisions (i.e., informational justice). Items for informational justice include questions that focus on the interpersonal behavior of the supervisor. Overall, two factors of procedural justice will be measured: the fairness of the formal procedures used, and the fairness of the interactions that enacted those formal procedures. This scale is based on one used by Moorman (1991), and has reported reliabilities above .90. Work Overload scale, O' Reilly's role overload scale (1982) with 13 items was used to measure role overload. The scale was a 5-point Likert-type scale, with a range of 1 , indicating strongly disagree, to 5, indicating strongly agree. The reliability of Reilly's overload scale has been well documented. The computed value of Cronbach's alpha was .88 in Reilly's original study. Jones et al. (2007) used Reilly's scale to measure role overload of salespeople and obtained a composite reliability of .94. Thiagarajan et al. (2006) performed a factor analysis of Reilly's scale to determine the unidimensionality of the scale. Thiagarajan et al (2006) reported a reduced version appeared to be a reliable and valid measure with fit indexes exceeding .95. The study included the use of the 13-item scale.

Procedure - The study began with ascertaining that the appropriateness of the instruments for the study. The instruments were used for quantitative data from the sample in line with correlation design of the study. Purposive sampling was used to select the organized public 
sector organizations in Asaba, the State capital of Delta State while cluster sampling technique was utilized in selecting organized private sector organizations located within an area. With the aid of trained research volunteers, data was collated from the population. Participation in the study was voluntary as participants reserved the right not to participate in the study. The instruments were self-reported questionnaire which took about 18 minutes to respond to the items. From 400 questionnaires, 385 valid responses were extracted for analysis. The responses to the items where coded in statistical package for scientific studies SPSS version 21.00. The data were explored to ascertain correlation among variables of the study used stepwise regression analysis. The result of the analysis was reported in the result section.

\section{Results}

Table 1: table of mean and standard deviation of all the variables (counterproductive work behavior, work overload, distributive justice and procedural justice) examined in this study

\begin{tabular}{llll}
\hline & Mean & Std. Deviation & N \\
\hline Counterproductive work & 46.4118 & 2.19772 & 385 \\
behavior & 47.5647 & 6.23249 & 385 \\
work overload & 29.8471 & 3.48306 & 385 \\
distributive justice & 19.8471 & 2.72859 & 385 \\
procedural justice &
\end{tabular}

Data in Table 1 reports the descriptive statistics of the variable indicating that based on the norm score of 45.62 for the CWB scale, the participants' mean of 46.41 was high. This means that there is prevalence of counterproductive work behaviour among the participants of the study. 
Table 2: Zero Order Inter-item Correlation Matrix

\begin{tabular}{|c|c|c|c|c|c|}
\hline & CWB & DJ & PJ & IJ & WO \\
\hline $\begin{array}{l}\text { Counterproductive work } \\
\text { behaviour (CWB) }\end{array}$ & 1 & & & & \\
\hline Distributive justice (DJ) & $-.485^{*}$ & 1 & & & \\
\hline \multirow[t]{3}{*}{ Procedural justice (PJ) } & $-.438 *$ & & 1 & & \\
\hline & & .650 & & & \\
\hline & & $* *$ & & & \\
\hline \multirow[t]{3}{*}{ Interactional Justice (IJ) } & $-.390^{*}$ & & & 1 & \\
\hline & & .617 & $.611^{*}$ & & \\
\hline & & $* *$ & $*$ & & \\
\hline \multirow[t]{2}{*}{ Work overload (WO) } & & - & - & - & 1 \\
\hline & $\begin{array}{l}.532 \\
*\end{array}$ & $.593 * *$ & $\begin{array}{l}.509 * \\
*\end{array}$ & .254 & \\
\hline
\end{tabular}

*significant at $\mathrm{p}<.05 ; * *$ significant at $\mathrm{p}<.01$

Tables 2 shows mixed correlation among variables. Whereas there is positive and significant correlation between CWB and work overload at $r=.53^{*}, p<.05$, negative correlations were found in the relation between CWB and all the justice dimensions at DJ $=-.49 *, \mathrm{PJ}=-.44 *$ and $-.39 *$ all at $p<.05(n=385)$. This means that CWB has positive association with work overload but negative association with organizational justice dimensions.

Table3: Summary table of regression analysis with respect to work overload and organizational justice dimensions (procedural and distributive justice) as predictors of counterproductive work behavior.

\begin{tabular}{|c|c|c|c|c|c|c|}
\hline Model & & B & $\begin{array}{l}\text { Unstandardized } \\
\text { Coefficients }\end{array}$ & $\begin{array}{l}\text { Standardized } \\
\text { Coefficients }\end{array}$ & $T$ & Sig \\
\hline \multirow[t]{4}{*}{1} & (Constant) & .13 & .12 & & 1.22 & .23 \\
\hline & Work overload & 1.56 & .01 & .57 & 8.213 & $.00 *$ \\
\hline & Distributive Justice & -.47 & .01 & -.52 & -2.764 & $.01 *$ \\
\hline & procedural justice & -.35 & .02 & -.40 & -3.111 & $.00 *$ \\
\hline
\end{tabular}

Dependent variable: Counterproductive work behaviour (CWB) *significant at $p<.05$

Result in Table 3 reveals a mixed result. The predictive effects of work overload on CWB was positive and significant at $\beta(3,385)=.57^{*}, p<.05$ implying that as work overload increases in the organization, counterproductive work behavior (CWB) also increases proportionally. However, the predictive effects of distributive justice (DJ) and procedural justice (PJ) were negative and significant at $\beta(3,385)=.52$ and $.40, p<.05$ respectively. This implies that as the justice dimensions (distributive and procedural) increases in the organization, counterproductive work behavior (CWB) decreases proportionally. The findings mean that overloaded workers are more likely to retaliate negatively to their organizations in acts adjudged as counterproductive or inimical to the organization. However, workers who perceive that there is both distributive and procedural justice are less likely to engage in counterproductive work behaviour against their organizations. 


\section{Discussion}

Counterproductive work behaviour is inimical to the organization and it works against the goals and objectives of the organization at huge cost and even humanitarian crises. No organization may be able to survive with unabated counterproductive work behaviour of employees. To this end, the current study attempted the exploration of the predictive impacts of organizational justice dimensions and work overload on counterproductive work behaviour. The authors sort to establish that the incidence of counterproductive work behaviour may be abated as organizational justice system improves. The findings of the study revealed negative and significant predictive impacts of organizational justice dimensions (distributive and procedural) on counterproductive work behaviour. The finding is supported by the theoretical framework of the study which was hinged on stress facilitation theory explain that in the course of unbearable stress or stressors, employees with tendency for deviance behaviours such as theft etc are more likely to exhibit counterproductive work behaviour. In the contest of this study, unfair distribution of organizational rewards and punishment may necessarily orchestrate stress on the employees and thus set off retaliatory behaviours as coping mechanisms. This is in line with Tufail et al (2017) which found that organizational rewards and organizational justice affect organizational citizenship behavior and counterproductive work behavior. The authors in this perspective identified organizational rewards as a motivational stimulant as well as a stressor if the reward is uneven and unfair across employees. Further supportive collaborations seem to be found in Al-A'wasa's (2018) study which found that organizational justice impacted counterproductive work behavior (CWB) of employees suggesting that organizational justice dimensions have negative impacts on CWB. Also, Wu et al. (2016) found that there is a moderated mediation model of relationship between perceived organizational justice and counterproductive work. The procedural nature of justice equally reflects this negative antecedent on CWB; this was supported in the study of Hassard et al. (2018) which found that the financial burden of psychosocial workplace aggression. Equally, Etodike et al (2017) confirmed a positive and significant relationship between abusive supervision which is a type of procedural injustice and counterproductive workplace behaviour emphasizing that the model is consistent with human attitude in the workplace. As regards work overload, findings indicative that counterproductive workplace behaviour seem to increase in the presence of increasing overload on the employee task menu in terms of time, resources and personnel to accomplish the tasks. This is supported by Ezeh et al (2017) which found that work overload positively and significantly correlated work stress. In line with stress facilitation theory, work stress or stressors at work increases the chances of injurious behaviours to the organization in the absence of proper coping mechanisms. These instances suggest that overloaded employees may found reasons for retaliatory behaviour against the organization is their perception of the situation is negative oriented.

\section{Implications of the Study}

The results imply that the more employees are overloaded with work, the more chances they are going to perceive their work as stressful and if not adequately compensated may likely engage in counterproductive work behavior as compensation. In contrast, the results indicated that maintenance of organizational justice (procedural and distributive justice) brings about reduction in counterproductive work behavior among employees. 


\section{Recommendation}

The paper recommended that organizations should find ways of reducing work overload while ensuring that their employees are being treated fairly. Employers should avoid showing favoritism toward one employee in an organization; all favors and punishments should be showed to all employees irrespective of race, age, religion, disability, sexual orientation, gender or any other quality.

\section{Suggestion for Further Studies}

There will be the need to established factors which could moderate the relationship between organizational justice dimensions and counterproductive work behaviour. Also, it is important to identify which aspect of overload is most implicated in the model.

\section{Conclusion}

The paper explored the roles of work overload and organizational justice dimensions on counteproductive work behaviour. The paper raised some objectives, which are to determine if work overload will significantly predict counterproductive workplace behavior among employees and to determine if organizational justice dimensions will significantly predict counterproductive workplace behavior among employees. From the findings it mixed results was revealed; positive and significant predictive effect for work overload and negative and significant predictive effect for distributive justice procedural justice. The study concludes that the tendency to overload employees will be detrimental to the organization as the employees may retaliate negatively as a form of compensation for their exploitation. However, the general tendency for counterproductive work behaviour will be drastically reduced with improvements on organizational justice dimensions.

\section{References}

Adams, J. S. (1963). Inequity in social exchange. In L. Berkowitz (ed.), Advances in Experimental Social Psychology, Vol. 2 (pp. 267-299). New York: Academic Press.

Al-A' wasa, S. I. S. (2018). The impact of organizational justice on the counterproductive work behavior (CWB): A field study conducted in the Jordan Customs Department (JCD). International Journal of Business and Social Science, 9(1), 27-38.

Ansari, M. E., Maleki, V., Mazraeh, S., \& Arab-Khazaeli, H. (2013). Individual, Job, and Organizational Predictors of Counterproductive Work Behavior. Journal of Basic and Applied Scientific Research 3(4)78-86.

Babamiri, M., Sabbagh, U., \& Harsini, A. (2013). Investigate the Relationship between Organizational Justice and Personality Characteristics with Counterproductive Work Behavior; Journal of Life Science and Biomedicine 4, 67-79.

Barshir, A. (2009). Organizational justice perceptions as predictor of job satisfaction and commitment International journal of Business Mgt,4(9) 145-154.

Bennett, R. J., \& Robinson, S. L. (2000). Development of a measure of workplace deviance. Journal of Applied Psychology, 85(3), 349-360.

Brown, D., \& Leigh, L. (1996). Organizational climate scale.

Ehigie, B. O., \& Hameed, S. A. (2020). Emotional intelligence and organizational constraints as predictors of counterproductive work behaviour among teachers in abeokuta metropolis, Ogun State. International Journal of Scientific and Research Publications, 10(6), 90-101. 
Etodike, C. E., \& Ezeh, L. N. (2017). Perceived Workplace Incivility: A predictive Study of emotional regulation and marital Ssatus among administrative Staff of Nigeria Universities. Scholars Journal of Economics, Business and Management, 4(8), 504508. http://saspjournals.com/sjebm. DOI: $10.21276 /$ sjebm

Etodike, C. E., Ezeh, L. N., \& Chukwura, E. N. (2017). Abusive Supervision: A Predictor of Employee Cynicism and Counterproductive Workplace Behaviour among Industrial Workers. Scholars Journal of Arts, Humanities and Social Sciences, 5(9c), 1276-1283. ISSN 2347-5374. http://saspjournals.com/sjahss. DOI: 10.21276/sjahss.2017.5.9.25

Etodike, C. E., Ezeh, L. N., \& Chukwura, E. N. (2017). Life Satisfaction and Perceived Social Support as Predictors of Retirement Stress among Nigeria Public Service Retirees. International Journal of Current Advanced Research, 6(2), 23012311.www.journalicar.org.

Etodike, C. E., Ezeh, L. N., Ogbeide, D. E. O., \& Ike, P. R. (2018). Typical Solution to the Unemployment Problems in Nigeria: The Convergence Utility of the Entreprenuership Models. European Journal of Human Resource Management Studies 1(2), 130-138. http://www.oapub.or/soc DOI: 10.5281/zenodo.1253337

Etodike, C. E., Joe-Akunne, C. O., \& Obibuba, I. M. (2020). Employee Deviance as By-product of Psychological Contract: The Moderating Effects of Power Distance among Employees in Insurance Companies in Nigeria. Asian Journal of Arts \& Social Sciences, 10(4), 44-54 DOI: $\quad 10.9734 /$ ARJASS/2020/v10i430157 http:// journalarjass.com/index.php/ARJASS/article/view/430157

Etodike, C. E., Nnaebue, C. I., Iloke, S. E., \& Anierobi, E. I. (2020). Organizational Identification and Proactive Work Behaviour as Predictors of Cyber-Loafing among Anambra State Civil Servants. Asian Journal of Advanced Research and Reports, 8(2), 10-19. DOI: 10.9734/AJARR/2020/v8i230194

http://journalajarr. com/index.php/AJARR/article/view/53974

Ezeh, L. N., \& Etodike, C. E. (2017). Corruption in Nigeria organizations: theories \& implications. In Proceedings of Annual Scientific Conference of NPA, Promotion of Peaceful and Inclusive Societies for Sustained Development through Psychology held at Nnamdi Azikiwe University Awka, Nigeria, $11^{\text {th }}-14^{\text {th }}$ Oct. 2016

Ezeh, L. N,. \& Etodike, C. E. (2017). Work overload and distributive injustice as predictors of occupational stress among Health workers. International Journal in Management and Social Science, 5(7), 537-547. http://www.ijmr.net.in. ISSN:2321-1784.

Ezeh, L. N., Etodike, C. E., \& Chukwura, E. N. (2018). Abusive Supervision and Organizational Cynicism as Predictors of Cyber-Loafing among Federal Civil Service Employees in Anambra State - Nigeria. European Journal of Human Resource Management Studies, 1(2), 19-36. http://www.oapub.org/soc DOI: 10.5281/zenodo.1172162.

Ezeh, L. N., Etodike, C. E., \& Ike, P. R. (2017). Employee Turnover Intention: A predictive Study of Organizational Politics, Leader-Member Exchange and Job Insecurity. International Journal of Current Advanced Research, 6(2), 2294-2300. www.journal ijcar.org

Ezeh, L. N., Etodike, C. E., Nnaebue, C. I., Okafor, R. A., \& Iloke, S. E. (2020). Association of Innovative Work Behaviour, Organizational Frustration and Work-Family Conflict among Private Sector Employees. Asian Journal of Advanced Research and Reports, 8(2), 20-29. DOI: $\quad$ 10.9734/AJARR/ 2020/v8i230195 //journalajarr.com/index.php/AJARR/article/view/30145 
Ezeh, L. N., Ogbeide, D. E. O., Ike, P. R., \& Etodike, C. E. (2018). Distributive Injustice: A Predictive Study of Corruption and Office Abuse among Police Officers in Anambra State Police Command, Nigeria. European Journal of Social Sciences Studies, 2(11), 164-176. http://www.oapub.or/soc DOI: 10.5281/zenodo.1253008

Ezeh, L. N., Ogbeide, D. E. O., Ike, P. R., \& Etodike, C. E. (2018). Distributive Injustice: A Predictive Study of Corruption and Office Abuse among Police Officers in Anambra State Police Command, Nigeria. European Journal of Social Sciences Studies, 2(11), 164-176. http://www.oapub.or/soc DOI: 10.5281/zenodo.1253008

Fagbohungbe, B. O., Akinbode, G. A., \& Ayodeji, F. (2012). Gender and Organizational Factors as Determinants of Workplace Fraudulent Behaviours in Nigeria: An Empirical Analysis. International Journal of Business Trends and Technology, 2(2), 102-111.

Greenberg, J. (1987). Taxonomy of organizational justice theory. An academic directory.

Hassard, J., Teoh, K. R., Visockaite, G., Dewe, P., \& Cox, T. (2018). The financial burden of psychosocial workplace aggression: A systematic review of cost-of-illness studies. Work \& Stress, 32(1), 6-32.

Ike, P. R., Ezeh, L. N., \& Etodike, C. E. (2017). Employee Participation in Decision Making: A correlate of Employee Citizenship Behaviour and Counterproductive Workplace Behaviour. Journal of Academic Research in Business and Social Sciences, 7(7), 934-948. http://dx.doi.org/10.6007 /IJARBSS/v7-i73179 DOI: 10.6007/IJARBSS/v7-i73179

Joe-Akunne, C. O., Ogbeide, D. E. O., \& Etodike, C. E. (2018) Employee Involvement: A Predictive Study of Organizational Climate Dimensions among Private Sector Employees. Scholars Journal of Economics, Business and Management (SJEBM) 5(12), 131-139. http://saspjournals.com/sjebm DOI: 10.21276/sjebm.2018.5.12.6

Jones, D. A. (2009). Getting even with one's supervisor and one's organization: Relationships among types of injustice, desires for revenge, and counterproductive work behaviors. Journal of Organizational Behavior, 30, 525-542.

Kalleberg, A. L. (2008), "The mismatched worker: When people don't fit their jobs." Academy of Management Perspectives, 22(1), 24-40.

Reilly, M. D. (1982). Working wives and convenience consumption. Journal of Consumer Research, 10, 407-418. Retrieved May 15, 2020, from proQuest database.

Sackett, P., Berry, C., Wiemann, S., \& Laczo, R. (2006). "Citizenship and Counterproductive Behavior: Clarifying Relations Between the two Domains". Human Performance. 19 (4): 441-64. doi:10.1207/s15327043hup1904_7

Syal, A. (2019). The Role of Envy and Perceived Ethical Climate in Responsible Leadership and Employee Outcomes. Academy of Management Global Proceedings, (2019), 395.

Tufail, M. S., Muneer, S., \& Manzoor, M. (2017). How organizational rewards and organizational justice affect the organizational citizenship behavior and counterproductive work behavior: Analysis of Pakistan service industries. City University Research Journal, 171-182.

Wu, M., Sun, X., Zhang, D., \& Wang, C. (2016). Moderated mediation model of relationship between perceived organizational justice and counterproductive work behavior. Journal of Chinese Human Resource Management. 7(2), 64-81. https://doi.org/10.1108/JCHRM07-2016-0016

Yusof, R. M., Yunus, N. K. Y., \& Adnan, A. A. Z. (2019). Examining Moderating Effect of Industrial Relations Climate on Workplace Spirituality and Counterproductive Work Behaviour. International Journal of Academic Research in Accounting, Finance and Management Sciences, 9(3), 353-363. 